\title{
Complete genome sequence of Pseudomonas corrugata strain RM1-1-4, a stress protecting agent from the rhizosphere of an oilseed rape bait plant
}

\author{
Christin Zachow ${ }^{1 *}$ (D) Henry Müller ${ }^{2}$, Christina M. Laireiter ${ }^{1,2}$, Ralf Tilcher ${ }^{3}$ and Gabriele Berg ${ }^{2}$
}

\begin{abstract}
Pseudomonas corrugata strain RM1-1-4 is a rhizosphere colonizer of oilseed rape. A previous study has shown that this motile, Gram-negative, non-sporulating bacterium is an effective stress protecting and biocontrol agent, which protects their hosts against abiotic and biotic stresses. Here, we announce and describe the complete genome sequence of P. corrugata RM1-1-4 consisting of a single $6.1 \mathrm{Mb}$ circular chromosome that encodes 5189 protein coding genes and 85 RNA-only encoding genes. Genome analysis revealed genes predicting functions such as detoxifying mechanisms, stress inhibitors, exoproteases, lipoproteins or volatile components as well as rhizobactin siderophores and spermidine. Further analysis of its genome will help to identify traits promising for stress protection, biocontrol and plant growth promotion properties.
\end{abstract}

Keywords: Pseudomonas corrugata, Sphagnum magellanicum-treated seeds, Rhizosphere of bait plant, Stress protection, Detoxification systems, Biocontrol, Plant growth promotion

\section{Introduction}

Pseudomonas corrugata Roberts and Scarlett (1981) emend. Sutra belongs to the genus Pseudomonas sensu stricto and it is one of the few non fluorescent Pseudomonas species. $P$. corrugata strain RM1-1-4 was isolated from the oilseed rape rhizosphere grown in the greenhouse, whose seeds were treated with the microbial community associated with the moss Sphagnum magellanicum [1]. Sphagnum mosses form bog ecosystems under low-nutrient and extreme conditions supported by their microbiota [2]. RM11-4 was selected as stress protecting agent coping high salt concentrations, reactive oxygen species and desiccation [1]. As it has a broad antagonistic spectrum exhibiting antifungal activity against phytopathogenic fungi (Ascomycota: Alternaria alternata, Botrytis cinerea, Sclerotinia sclerotiorum, Verticillium dahliae and Basidiomycota: Rhizoctonia solani AG2-2IIIB, Sclerotium rolfsii), it is a promising candidate for biocontrol purposes. The activity putatively base on

\footnotetext{
* Correspondence: christin.zachow@acib.at

${ }^{1}$ Austrian Centre of Industrial Biotechnology (ACIB GmbH), Petersgasse 14, 8010 Graz, Austria

Full list of author information is available at the end of the article
}

the production of exoenzymes and the emission of antimicrobial volatile organic compounds.

In this report, we summarize the complete genome sequence and annotation of RM1-1-4. We also describe its genomic properties revealing multifaceted plant beneficial features. The genome sequence of RM1-1-4 and its comparison with related published genomes will provide a framework for further functional studies of its abiotic and biotic stress protecting effectiveness in plant and rhizosphere competence.

\section{Organism information Classification and features}

$P$. corrugata RM1-1-4 is a motile, Gram-negative, nonsporulating rod in the order Pseudomonadales of the class Gammaproteobacteria. The rod-shaped cells are approximately $0.5 \mu \mathrm{m}$ in width and $1.5-2.0 \mu \mathrm{m}$ in length (Fig. 1 left). The strain is moderately fast-growing, forming $1 \mathrm{~mm}$ colonies within $1-2$ days at $25{ }^{\circ} \mathrm{C}$. Colonies formed on nutrient broth II (NBII) agar plates [1] are yellow opaque shining, domed and moderately mucoid with smooth margins (Fig. 1 right). No fluorescence of 


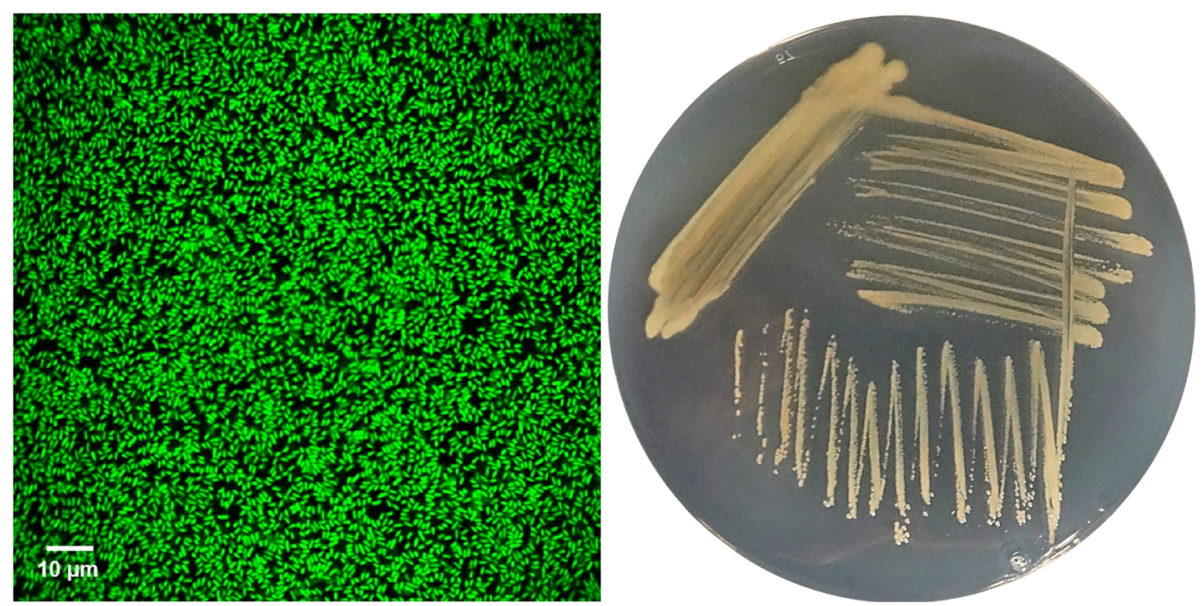

Fig. 1 Photomicrographs of source organism. Image of $P$. corrugata RM1-1-4 cells using confocal laser scanning microscopy (CLSM, left) and the appearance of colony morphology after $48 \mathrm{~h}$ growing on NB agar medium at $25^{\circ} \mathrm{C}$ (right). Image was obtained using acridin orange $\left(0.4 \mathrm{mg} \mathrm{mL}{ }^{-1}\right.$ water) stained RM1-1-4 cells with 40× magnification. Cells under Leica TCS SP CLSM (Leica Microsystems, Wetzlar, Germany) captured and analysed using Leica Application Suite Advanced Fluorescence (LAS AF) software Version 3.5

the cells was visualized under UV light $(312 \mathrm{~nm})$ when grown on King's B agar. RM1-1-4 was isolated from the roots of healthy oilseed rape plants cv. Traviata KWS (KWS SAAT SE, Einbeck, Germany), whose seeds were treated with a microbial suspension of Sphagnum magellanicum [1].

Even though the optimal growth temperature is $30{ }^{\circ} \mathrm{C}$, RM1-1-4 can also slowly replicate at $5{ }^{\circ} \mathrm{C}$ in liquid Luria Bertani (LB). Growth was observed at $37^{\circ} \mathrm{C}$ and slightly at $40{ }^{\circ} \mathrm{C}$ in this culturing medium and on solidified medium after $24 \mathrm{~h}$. The strain grows in complex media (LB, NBII), but not in Standard Succinate Medium (pH 7.0). Optimum $\mathrm{pH}$ for growth in $\mathrm{LB}$ is $\mathrm{pH}$ 6.0. It does not cause any deleterious effect on its original host (oilseed rape) or maize, sorghum and sugar beet [1]. Strain RM1-1-4 has natural resistance to gentamycin $\left(10 \mu \mathrm{g} \mathrm{mL} L^{-1}\right)$, trimethoprim $\left(50 \mu \mathrm{g} \mathrm{mL} L^{-1}\right)$ and is able to develop spontaneous rifampicin-resistance.

Minimum Information about the Genome Sequence (MIGS) of $P$. corrugata RM1-1-4 is summarized in Table 1 . The phylogenetic relationship of $P$. corrugata RM1-1-4 to other species within the genus Pseudomonas is visualized in a 16S rRNA based tree [3] and a tree based on the oligopeptide content of the complete protein sequence by using a Composition Vector Tree (CVTree) approach [4, 5] (Fig. 2a, b).

\section{Genome sequencing information \\ Genome project history}

The genome of $P$. corrugata strain RM1-1-4 was selected for sequencing based on its ability to exert stress protecting abilities against abiotic and biotic stresses and to promote plant growth. The strain was isolated from the rhizosphere of an oilseed rape plant that was subjected to a bait plant strategy: oilseed rape seeds were treated with the microbial community of Sphagnum magellanicum [1], where RM1-1-4 was originally identified as $P$. fluorescens. After Average Nucleotide Identity (ANI) [6] comparison of the genome sequence against the genomes of the type strains and proxytype strains that are already in GenBank, RM1-1-4 showed $99.585 \%$ identity to the type genome of $P$. corrugata with $97 \%$ coverage of the genome. To clarify the taxonomic affiliation we performed a systematic method of inferring evolutionary relatedness of microbial organisms from the 16S rRNA gene region (Fig. 2a) and the oligopeptide content of their complete protein sequences by using CVTree showing its phylogenetic positioning (Fig. 2b) [3-5]. The genome project is deposited in the NCBI BioProject PRJNA309490 database with the Biosample SAMN04453325. This whole genome shotgun project has been deposited in the NCBI database under the accession no. CP014262 (Table 2).

\section{Growth conditions and genomic DNA preparation}

P. corrugata strain RM1-1-4 was grown in $50 \mathrm{~mL}$ of NBII (Sifin, Berlin, Germany) medium and incubated for $20 \mathrm{~h}$ at $30^{\circ} \mathrm{C}$. $0.5 \mathrm{~mL}$ were centrifuged at $2500 \mathrm{x}$ g for 5 min at $4{ }^{\circ} \mathrm{C}$ and genomic DNA was extracted using the MasterPure DNA purification kit (Epicentre, Madison, WI, USA). DNA quality and quantity were checked by agarose gel electrophoresis and spectrophotometry using a UV-Vis spectrophotometer (NanoDrop 2000c, Thermo Fisher Scientific, Waltham, MA USA). In total, $91 \mu \mathrm{g}$ genomic DNA $\left(3.1 \mu \mathrm{g} \mu \mathrm{L}^{-1}\right)$ was sent on dry ice to the sequencing service. PacBio RS libraries with inserts of 8 to $20 \mathrm{~kb}$ were constructed and sequenced at GATC Biotech (Konstanz, Germany). 
Table 1 Classification and general features of P. corrugata RM11-4 according to the MIGS recommendation [24]

\begin{tabular}{|c|c|c|c|}
\hline MIGS ID & Property & Term & $\begin{array}{l}\text { Evidence } \\
\text { code }^{\mathrm{a}}\end{array}$ \\
\hline & \multirow[t]{8}{*}{ Classification } & Domain Bacteria & TAS [25] \\
\hline & & Phylum Proteobacteria & TAS [26] \\
\hline & & Class Gammaproteobacteria & TAS [27] \\
\hline & & Order Pseudomonadales & $\operatorname{TAS}[28,29]$ \\
\hline & & Family Pseudomonadaceae & $\operatorname{TAS}[26,30]$ \\
\hline & & Genus Pseudomonas & TAS [31-34] \\
\hline & & $\begin{array}{l}\text { Species Pseudomonas } \\
\text { corrugata }\end{array}$ & TAS [34] \\
\hline & & Strain: RM1-1-4 & TAS [1] \\
\hline & Gram stain & Negative & IDA, TAS [34] \\
\hline & Cell shape & Rod-shaped & IDA, TAS [34] \\
\hline & Motility & Motile & TAS [34] \\
\hline & Sporulation & None & NAS \\
\hline & Temperature range & $5^{\circ} \mathrm{C}-40^{\circ} \mathrm{C}$ & IDA \\
\hline & $\begin{array}{l}\text { Optimum } \\
\text { temperature }\end{array}$ & $30^{\circ} \mathrm{C}$ & IDA \\
\hline & pH range; Optimum & $5-9 ; 6$ & IDA \\
\hline & Carbon source & Heterotrophic & TAS [34] \\
\hline MIGS-6 & Habitat & Soil, Rhizosphere & TAS [1] \\
\hline MIGS-6.3 & Salinity & $1-9 \% \mathrm{NaCl}(w / v)$ & IDA, TAS [1] \\
\hline MIGS-22 & Oxygen requirement & Aerobic & TAS [34] \\
\hline MIGS-15 & Biotic relationship & Rhizospheric & TAS [1] \\
\hline \multirow[t]{4}{*}{ MIGS-14 } & Pathogenicity & Non-pathogen & TAS [1] \\
\hline & Host & Brassica napus L. & TAS [1] \\
\hline & Host taxa ID & 3708 & \\
\hline & Biosafety level & 1 & NAS \\
\hline MIGS-4 & Geographic location & Graz, Austria & TAS [1] \\
\hline MIGS-5 & $\begin{array}{l}\text { Sample collection } \\
\text { time }\end{array}$ & 2010 & TAS [1] \\
\hline MIGS-4.1 & Latitude & 47.065545 & NAS \\
\hline MIGS-4.2 & Longitude & 15.453093 & NAS \\
\hline MIGS-4.4 & Altitude & $1340 \mathrm{~m}$ & NAS \\
\hline
\end{tabular}

${ }^{\mathrm{a}}$ Evidence codes - IDA: Inferred from Direct Assay; TAS: Traceable Author Statement (i.e., a direct report exists in the literature); NAS: Non-traceable Author Statement (i.e., not directly observed for the living, isolated sample, but based on a generally accepted property for the species, or anecdotal evidence). These evidence codes are from the Gene Ontology project [35]

\section{Genome sequencing and assembly}

PacBio RS libraries with inserts of 8 to $20 \mathrm{~kb}$ were constructed and sequenced at GATC Biotech (Konstanz, Germany) using single molecule, real-time (SMRT) sequencing. Assembly was completed with the Hierarchical Genome Assembly Process (HGAP) algorithm implemented in the PacBio SMRT Analysis software (Pacific Biosciences, Menlo Park, CA, USA). The assembly of RM1-1-4 genome based on 161,326 quality reads with a mean length of 5315 bp resulting in a single circular chromosome of 6,124,363 bp, with 118.0-fold overall coverage and a GC content of $60.7 \%$.

\section{Genome annotation}

Automatic annotation was conducted on the RAST Web server (version 36) using RAST gene calling based on FIGfam version Release70 [7, 8], and additional annotation for using the automated assignment of COGfunctions to protein-coding genes was completed on the BASys web server using Glimmer gene prediction $[9,10]$. Pseudogenes were predicted using the NCBI Prokaryotic Genome Annotation Pipeline. Signal peptides and transmembrane helices were predicted using SignalP $[11,12]$.

\section{Genome properties}

The genome of RM1-1-4 is composed of one circular chromosome consisting of $6,124,363 \mathrm{bp}$ with an average GC content of $60.7 \%$ (Table 3 and Fig. 3), which is comparable to that of other $P$. corrugata strains. Among the 5335 predicted genes, 5189 were identified as protein coding genes of which 4110 (79.2\%) were assigned as putative function, while the other 1079 (20.8\%) were designated as hypothetical proteins. The classification of CDSs into functional categories according to the COG (Clusters of Orthologous Groups) [13, 14] database is summarized in Table 4 on BASys gene prediction. Beside the predicted genes, the genome annotation revealed 65 tRNA, five rRNA loci $(5 S, 16 S, 23 S)$ with one additional $5 \mathrm{~S}$ rRNA, four ncRNAs and 284 predicted SEED subsystem features.

\section{Insights from the genome sequence}

The genome encodes genes that can be linked to detoxification mechanisms of oxygen radicals, toxins and heavy metals by efflux pumps as well as to stress response by heat and cold shock proteins and the universal stress protein A (UspA). UspA with orthologues (Locus Tags AXG94_02180, AXG94_04130, AXG94_24005, AXG94_ 24695) could play a significant role in protecting RM1-1-4 cells from $\mathrm{H}_{2} \mathrm{O}_{2}$ and low $\mathrm{pH}$ as found in organisms inhabiting extreme environments [15] and analysed in detail for the clinical strain Acinetobacter baumannii ATCC 17978 [16]. A water stress/hypersensitive response protein (AXG94_21760) is present, which is supposed to be transferred to symbiotic or pathogenic bacteria by horizontal gene transfer from plants and can be seen as the acquisition of a function putatively related to the cell defense [17]. The genome of RM1-1-4 contains several genes, which are important contributors to biological control. They are related to the biosynthesis of secondary metabolites or antimicrobial products that are similar to those found in the genomes of other Pseudomonads: productions of exoproteases and lipoproteins [18]. We further identified genes 


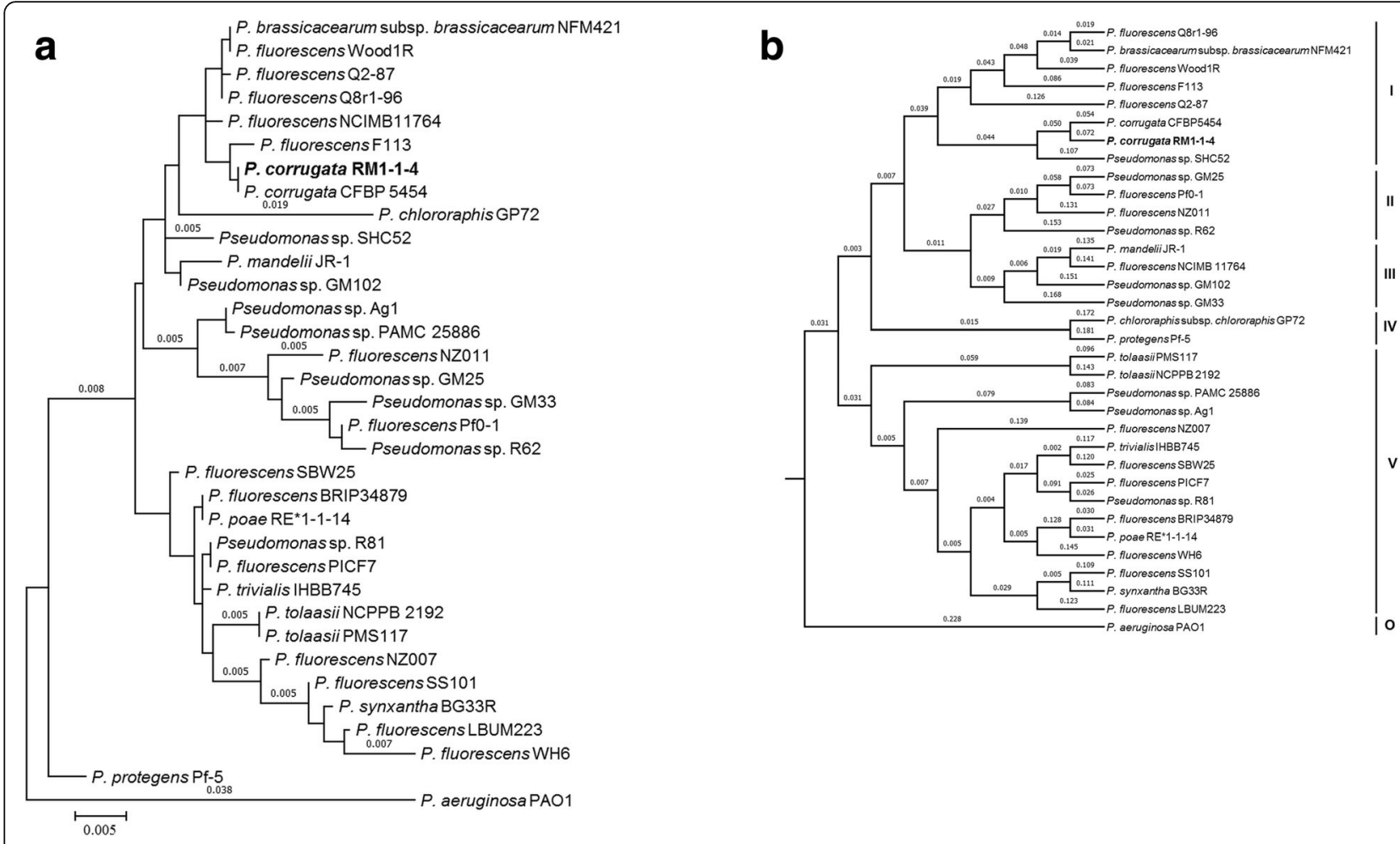

Fig. 2 Phylogenetic tree showing the position of P. corrugata RM1-1-14 in relationships among other strains of Pseudomonas spp. including $P$. aeruginosa PAO1 as outgroup. a The tree is based on 16S rRNA gene alignments and was conducted in MEGA6 [3]. Initial tree for the heuristic search were obtained automatically by applying Neighbor-Join and BioNJ algorithms to a matrix of pairwise distances estimated using the Maximum Composite Likelihood approach, and then selecting the topology with superior log likelihood value. $\mathbf{b}$ The dendrogram based on protein sequences for representative strains belonging to the existing five subgroups $(\mathrm{I}-\mathrm{V})$ of the $P$. fluorescens complex including $P$. aeruginosa PAO1 as outgroup $(\mathrm{O})$ and was created by using Composition Vector Approach [5]

Table 2 Project information

\begin{tabular}{|c|c|c|}
\hline MIGS ID & Property & Term \\
\hline MIGS 31 & Finishing quality & Finished \\
\hline MIGS-28 & Libraries used & $\begin{array}{l}\text { PacBio RS libraries with inserts } \\
\text { of } 8 \text { to } 20 \mathrm{~kb}\end{array}$ \\
\hline MIGS 29 & Sequencing platforms & PacBio RS II sequencer \\
\hline MIGS 31.2 & Fold coverage & 118.0 \\
\hline MIGS 30 & Assemblers & $\begin{array}{l}\text { Hierarchical Genome Assembly } \\
\text { Process (HGAP) algorithm } \\
\text { implemented in the PacBio } \\
\text { SMRT Analysis software }\end{array}$ \\
\hline \multirow[t]{6}{*}{ MIGS 32} & Gene calling method & $\begin{array}{l}\text { Glimmer gene prediction, NCBI } \\
\text { Prokaryotic Genome Annotation } \\
\text { Pipeline }\end{array}$ \\
\hline & Locus Tag & AXG94 \\
\hline & Genbank ID & СР014262 \\
\hline & GenBank Date of Release & July 31, 2016 \\
\hline & GOLD ID & $\begin{array}{l}\text { Gs0118516, Gp0137000, } \\
\text { Ga0115603 }\end{array}$ \\
\hline & BIOPROJECT & PRJNA309490 \\
\hline \multirow[t]{2}{*}{ MIGS 13} & Source Material Identifier & RM1-1-4 \\
\hline & Project relevance & $\begin{array}{l}\text { Plant-bacteria interaction, } \\
\text { agricultural, environmental }\end{array}$ \\
\hline
\end{tabular}

Table 3 Genome statistics

\begin{tabular}{lll}
\hline Attribute & Value & \% of Total \\
\hline Genome size (bp) & $6,124,363$ & 100 \\
DNA coding (bp) & $5,492,379$ & 89.7 \\
DNA G + C (bp) & $3,715,247$ & 60.7 \\
DNA scaffolds & 1 & - \\
Total genes & 5335 & 100 \\
Protein coding genes & 5189 & 97.3 \\
RNA genes & 85 & 1.6 \\
Pseudo genes & 61 & 1.1 \\
Genes in internal clusters & NA & - \\
Genes with function prediction & 4256 & 82.0 \\
Genes assigned to COGs & 4013 & 77.3 \\
Genes with Pfam domains & 3296 & 63.5 \\
Genes with signal peptides & 434 & 8.4 \\
Genes with transmembrane helices & 1365 & 26.3 \\
CRISPR repeats & NA & - \\
\hline
\end{tabular}




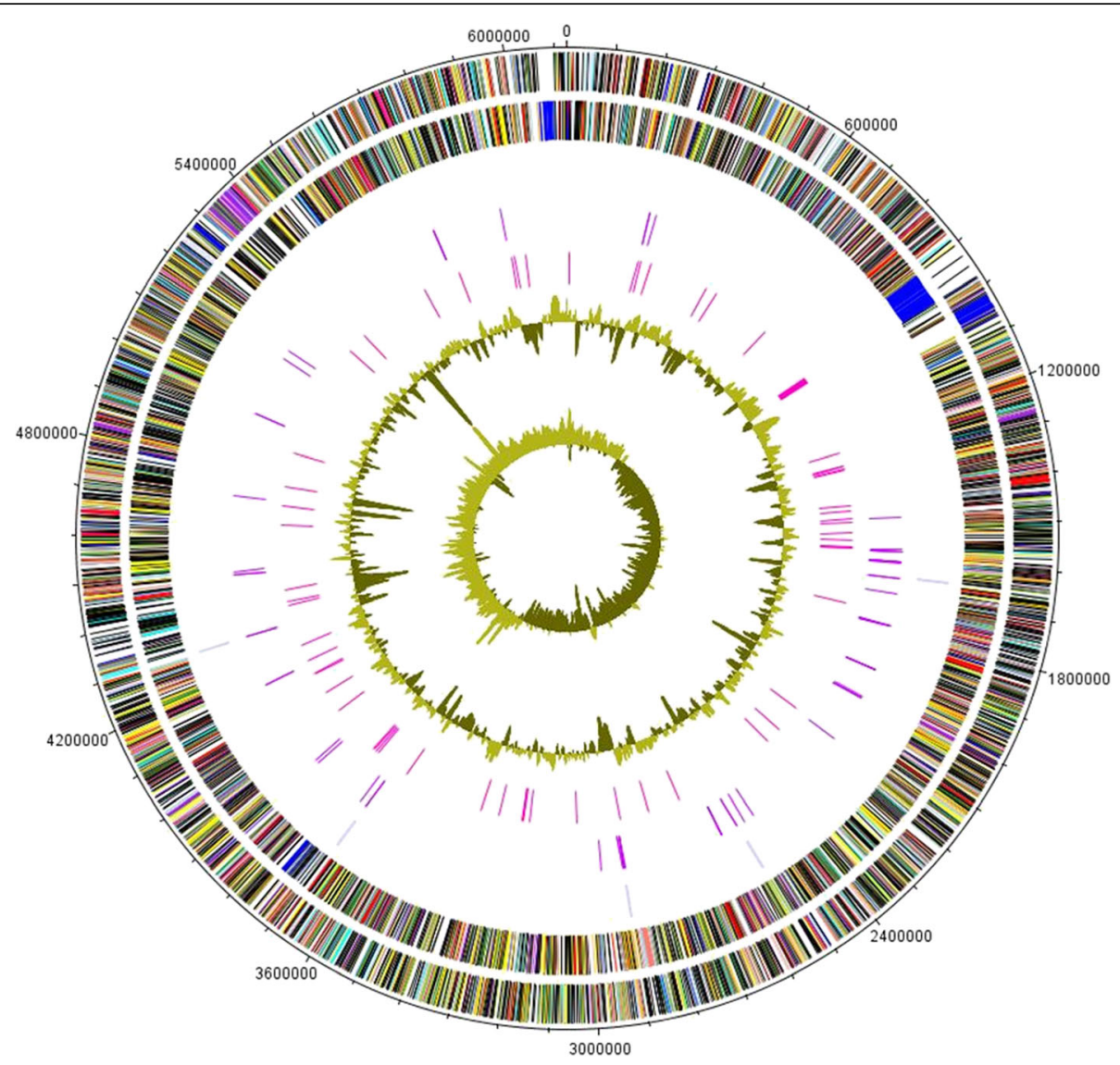

Fig. 3 Graphical map of the chromosome. The outer scale is marked every $10 \mathrm{~kb}$. Circles range from 1 (outer circle) to 7 (inner circle). Circle 1 and 2, ORFs encoded by leading and lagging strand respectively, with color code for functions: salmon, translation, ribosomal structure and biogenesis; aquamarine, RNA processing and modification; light blue, transcription; cyan, DNA replication, recombination and repair; tan, chromatin structure and dynamics; turquoise, cell division; dark orange, defense mechanisms; deep pink, post-translational modification, protein turnover and chaperones; dark olive green, cell envelope biogenesis; purple, cell motility and secretion; lavender, intracellular trafficking, secretion, and vesicular transport; forest green, inorganic ion transport and metabolism; pink, signal transduction; red, energy production; sienna, carbohydrate transport and metabolism; yellow, amino acid transport; orange, nucleotide transport and metabolism; gold, co-enzyme transport and metabolism; cornflower blue, lipid metabolism; blue, secondary metabolites, transport and catabolism; gray, general function prediction only; yellow green, unknown function; black, function unclassified or unknown. Circle 3 and 4, distributions of tRNA genes and rrn operons respectively. Circle 5, distribution of pseudogenes. Circle 6 and 7, G + C content and GC skew (G-C/G + C) respectively

most probably involved in the direct promotion of plant growth, such as biosynthesis or carrier gene clusters for aminocyclopropane-1-carboxylate deaminase suggested to be a key in the modulation of ethylene levels in plants by bacteria [19], auxin, biofilm dispersion, rhizobactin siderophores and spermidine.

Genes predicting the synthesis of volatile components are present in the RM1-1-4 genome as well. Volatile components have been shown to act as antibiotics and to induce plant growth $[20,21]$. An example is hydrogen cyanide $(\mathrm{HCN})$, an inorganic compound with antagonistic effects against soil microbes [22]. RM1-1-4 encodes a hydrogen cyanide synthase HcnA (AXG94_04380) and orthologues of genes required for the biosynthesis of other volatile components such as 2,3-butanediol (AXG94_01200) and its precursor acetoin (AXG94_01195) were annotated too. Beside the presence of specific genes and the noticeable ability of RM1-1-4 to expose stress protection, the function of particular genes needs to be clarified in further detailed studies.

The genome-wide phylogenetic analysis on Pseudomonas species [3-5] with the RM1-1-4 genome showed that strain RM1-1-4 clusters within the $P$. fluorescens group (Fig. 2a, b) and most closely to $P$. corrugata CFBP 5454 (DDBJ/EMBL/GenBank accession ATKI01000000). The two $P$. corrugata strains belong to the few non fluorescent Pseudomonas species. CFBP 5454 was originally described as the causal agent of the tomato disease called 'pith necrosis' and is yet considered as a biological resource in the fields of biocontrol of plant diseases and production of industrially promising microbial biopolymers like antimicrobial cyclic lipopeptides [23]. 
Table 4 Number of genes associated with general COG functional categories

\begin{tabular}{|c|c|c|c|}
\hline Code & Value & \%age & Description \\
\hline J & 161 & 2.41 & $\begin{array}{l}\text { Translation, ribosomal structure and } \\
\text { biogenesis }\end{array}$ \\
\hline A & 3 & 0.04 & RNA processing and modification \\
\hline K & 375 & 5.61 & Transcription \\
\hline L & 162 & 2.43 & Replication, recombination and repair \\
\hline B & 2 & 0.03 & Chromatin structure and dynamics \\
\hline D & 32 & 0.48 & $\begin{array}{l}\text { Cell cycle control, Cell division, } \\
\text { chromosome partitioning }\end{array}$ \\
\hline V & 61 & 0.91 & Defense mechanisms \\
\hline $\mathrm{T}$ & 235 & 3.52 & Signal transduction mechanisms \\
\hline M & 236 & 3.53 & Cell wall/membrane biogenesis \\
\hline N & 126 & 1.89 & Cell motility \\
\hline U & 42 & 0.63 & Intracellular trafficking and secretion \\
\hline $\mathrm{O}$ & 168 & 2.52 & $\begin{array}{l}\text { Posttranslational modification, protein } \\
\text { turnover, chaperones }\end{array}$ \\
\hline C & 270 & 4.04 & Energy production and conversion \\
\hline G & 247 & 3.70 & Carbohydrate transport and metabolism \\
\hline E & 445 & 6.66 & Amino acid transport and metabolism \\
\hline $\mathrm{F}$ & 79 & 1.18 & Nucleotide transport and metabolism \\
\hline $\mathrm{H}$ & 152 & 2.28 & Coenzyme transport and metabolism \\
\hline । & 182 & 2.72 & Lipid transport and metabolism \\
\hline$P$ & 197 & 2.92 & Inorganic ion transport and metabolism \\
\hline Q & 97 & 1.45 & $\begin{array}{l}\text { Secondary metabolites biosynthesis, } \\
\text { transport and catabolism }\end{array}$ \\
\hline $\mathrm{R}$ & 412 & 6.17 & General function prediction only \\
\hline S & 329 & 4.93 & Function unknown \\
\hline - & 2615 & 40.14 & Not in COGs \\
\hline
\end{tabular}

The total is based on the total number of protein coding genes in the genome based on BASys gene prediction

\section{Conclusions}

This report described the complete genome sequence of P. corrugata strain RM1-1-4. It is a "Pseudomonadales" within the non-fluorescent $P$. corrugata clade that was originally isolated from the roots of moss microbiomeprimed oilseed rape seeds cv. Traviata KWS grown in a greenhouse in Graz, Austria. This strain was selected for sequencing based on its ability to protect plants from abiotic and biotic stresses and to promote plant growth. We could highlight genes encoding abiotic and biotic stress protecting factors and other well-known bacterial traits for establishment of beneficial plant-microbe interactions. The genome encodes for a collection of genes predicting biofilm dispersion, detoxifying compounds, volatile components and enzymes such as a protease and a deaminase. Such properties likely have origins in a repertoire of genes including efflux pumps, putative
T2SS, T4SS and T6SS, and several genes presumably implicated in auxin, rhizobactin siderophore and spermidine production. Further functional studies and comparative genomics with related isolates will provide insights into naturally acquired plant stress protection and promotion of plant health.

\section{Abbreviations}

CDS: Coding DNA Sequence; CLSM: Confocal Laser Scanning Microscopy; COG: Clusters of Orthologous Groups; CVTree: Composition Vector Tree; HCN: Hydrogen Cyanide; HGAP: Hierarchical Genome Assembly Process; LB: Luria Bertani; NBII: Nutrient Broth II; RAST: Rapid Annotations using Subsystems Technology; SMRT: Single Molecule, Real-Time; T2SS: Type 2 Secretion System

\section{Acknowledgements}

The Authors thank Barbara Fetz for valuable assistance in DNA preparation. We are thankful to Eveline Adam and John H. Allan (University of Dundee) for performing growth experiments at different temperatures and $\mathrm{pH}$ values.

\section{Funding}

This work has been supported by the Federal Ministry of Science, Research and Economy (BMWFW), the Federal Ministry of Traffic, Innovation and Technology (bmvit), the Styrian Business Promotion Agency SFG, the Standortagentur Tirol, the Government of Lower Austria and ZIT - Technology Agency of the City of Vienna through the COMET-Funding Program managed by the Austrian Research Promotion Agency FFG.

\section{Authors' contributions}

$\mathrm{CZ}, \mathrm{HM}, \mathrm{RT}$ and $\mathrm{GB}$ conceived and designed the experiments. CZ and CML performed the phenotypic characterization. $\mathrm{HM}$ and $\mathrm{CZ}$ performed the annotation and sequence homology searches. CZ wrote the manuscript. All authors commented on the manuscript before submission. All authors read and approved the final manuscript.

\section{Competing interests}

The authors declare that they have no competing interests.

\section{Publisher's Note}

Springer Nature remains neutral with regard to jurisdictional claims in published maps and institutional affiliations.

\section{Author details}

${ }^{1}$ Austrian Centre of Industrial Biotechnology (ACIB GmbH), Petersgasse 14, 8010 Graz, Austria. ${ }^{2}$ Institute of Environmental Biotechnology, Graz University of Technology, Petersgasse 12, 8010 Graz, Austria. ${ }^{3}$ KWS SAAT SE,

Grimsehlstraße 31, 37555 Einbeck, Germany.

Received: 18 January 2017 Accepted: 24 October 2017

Published online: 09 November 2017

\section{References}

1. Zachow C, Müller H, Tilcher R, Donat C, Berg G. Catch the best: novel screening strategy to select stress protecting agents for crop plants. Agronomy. 2013;3(4):794-815.

2. Bragina A, Oberauner-Wappis L, Zachow C, Halwachs B, Thallinger GG, Müller $\mathrm{H}$, et al. The Sphagnum microbiome supports bog ecosystem functioning under extreme conditions. Mol Ecol. 2014;23(18):4498-510.

3. Tamura K, Stecher G, Peterson D, Filipski A, Kumar S. MEGA6: Molecular Evolutionary Genetics Analysis version 6.0. Mol Biol Evol. 2013;30:2725-9.

4. Redondo-Nieto M, Barret M, Morrisey JP, Germaine K, Martinez-Granero F, Barahona E, et al. Genome sequence of the biocontrol strain Pseudomonas fluorescens F113. J Bacteriol. 2012;194:1273-4.

5. Zuo G, Hao H. CVTree3 web server for whole-genome-based and alignmentfree prokaryotic phylogeny and taxonomy, genomics proteomics. Bioinformatics. 2015;13:321-31.

6. Federhen S, Rossello-Mora R, Klenk HP, Tindall BJ, Konstantinidis KT, Whitman WB, et al. Meeting report: GenBank microbial genomic taxonomy workshop (12-13 may, 2015). Standards in Genomic Sci. 2016;11(1):1. 
7. Aziz RK, Bartels D, Best AA, DeJongh M, Disz T, Edwards RA, et al. The RAST server: rapid annotations using subsystems technology. BMC Genomics. 2008:9:75

8. Overbeek R, Olson R, Pusch GD, Olsen GJ, Davis JJ, Disz T, et al. The SEED and the rapid annotation of microbial genomes using subsystems technology (RAST). Nucleic Acids Res. 2014:42:D206-D14.

9. Van Domselaar GH, Stothard P, Shrivastava S, Cruz JA, Guo A, Dong X, et al. BASys: a web server for automated bacterial genome annotation. Nucleic Acids Res. 2005;33:W455-W59.

10. Delcher AL, Harmon D, Kasif S, White O, Salzberg SL. Improved microbial gene identification with glimmer. Nucleic Acids Res. 1999;27:4636-41.

11. Emanuelsson O, Brunak S, von Heijne G, Nielsen H. Locating proteins in the cell using TargetP, SignalP and related tools. Nat Protoc. 2007;2:953-71.

12. Krogh A, Larsson B, von Heijne G, Sonnhammer EL. Predicting transmembrane protein topology with a hidden Markov model: application to complete genomes. J Mol Biol 2001;305:567-580.

13. Tatusov RL, Koonin EV, Lipman DJA. Genomic perspective on protein families, Science. 1997;278:631-7.

14. Clusters of Orthologous Groups. NCBI. 2015. http://www.ncbi.n/m.nih.gov/ COG. Accessed February 2016.

15. Tkaczuk KLA, Shumilin I, Chruszcz M, Evdokimova E, Savchenko A, Minor W. Structural and functional insight into the universal stress protein family. Evol Appl. 2013:6(3):434-49.

16. Elhosseiny NM, Amin MA, Yassin AS, Attia A. Acinetobacter baumannii universal stress protein a plays a pivotal role in stress response and is essential for pneumonia and sepsis pathogenesis. Int J Med Microbiol. 2015;305(1): 114-23.

17. Ciccarelli FD, Bork P. The WHy domain mediates the response to desiccation in plants and bacteria. Bioinformatics. 2005;21(8):1304-7.

18. Loper JE, Hassan KA, Mavrodi DV, Davis EW, Lim CK, Shaffer BT, et al. Comparative genomics of plant-associated Pseudomonas spp.: insights into diversity and inheritance of traits involved in multitrophic interactions. PLoS Genet. 2012;8(7): e1002784

19. Hardoim PR, van Overbeek LS, van Elsas JD. Properties of bacterial endophytes and their proposed role in plant growth. Trends Microbiol. 2008;16:463-71.

20. Ren Y, Strobel G, Sears J, Park M. Geobacillus sp., a thermophilic soil bacterium producing volatile antibiotics. Microb Ecol. 2010;60:130-6.

21. Ryu CM, Farag MA, CH H, Reddy MS, Wei HX, Paré PW, Kloepper JW. Bacterial volatiles promote growth in Arabidopsis. Proc Natl Acad Sci U S A. 2003;100: 4927-32.

22. Ahmad F, Ahmad I, Khan MS. Screening of free-living rhizospheric bacteria for their multiple plant growth promoting activities. Microbiol Res. 2008;163: 173-81.

23. Licciardello G, Ferraro R, Russo M, Strozzi F, Catara AF, Bella P, et al. Transcriptome analysis of Pseudomonas mediterranea and P. corrugata plant pathogens during accumulation of medium-chain-length PHAs by glycerol bioconversion. New Biotechnol. 2016. doi:10.1016/j.nbt.2016.07.006.

24. Field D, Garrity G, Gray T, Morrison N, Selengut J, Sterk P, et al. The minimum information about a genome sequence (MIGS) specification. Nat Biotechnol. 2008;26:541-7.

25. Woese CR. Towards a natural system of organisms: proposal for the domains archaea, Bacteria and Eucarya. Proc Natl Acad Sci U S A. 1990;87:4576-9.

26. Garrity GM, Bell JA, Lilburn T: Phylum XIV. Proteobacteria phyl. Nov. In: Garrity G, Brenner D, Krieg N, Staley J, editors. Bergey's manual of systematic bacteriology, volume 2, part B. 2nd ed. New York: Springer; 2005: p. 323.

27. Garrity GM, Bell JA, Class LT. III. Gammaproteobacteria class. nov. In: Bergey's manual of systematics of archaea and bacteria, John Wiley \& Sons, Inc. New York: Part B; 2015: p. 1. doi:10.1002/9781118960608.cbm00045.

28. Skerman VBD, McGowan V, Sneath PHA. Approved lists of bacterial names Int J Syst Bacteriol. 1980;30:225-420.

29. Orla-Jensen S. The main lines of the natural bacterial system. J Bacteriol. $1921 ; 6: 263-73$.

30. Winslow CEA, Broadhurst J, Buchanan RE, Krumwiede C, Rogers LA, Smith GH. The families and genera of the bacteria. Preliminary report of the committee of the society of American bacteriologists on characterization and classification of bacterial types. J Bacteriol. 1917;2:505-66.

31. Migula W. Über ein neues System der Bakterien. Arb Bakteriol Inst Karlsruhe. 1894;1:235-8.

32. Doudoroff M, Palleroni NJ. Genus Migula 1894, 237; nom. Cons. Opin. 5, Jud. Comm. 1952, 121. In: Buchanan RE, Gibbons NE, editors. Bergey's manual of determinative bacteriology. 8th ed. Baltimore: The Williams and Wilkins Co.; 1974. p. 217-43.

33. Commission J. Opinion 5: conservation of the generic name Migula 1894 and designation of aeruginosa (Schroeter) Migula 1900 as type species. Int bull Bacteriol Nomencl Taxon. 1952;2:121-2.

34. Palleroni NJ. Pseudomonadaceae. Bergey's manual of systematic bacteriology. In: Krieg NR, Holt JG, editors. . Baltimore: The Williams and Wilkins Co; 1984. p. 141-99.

35. Ashburner M, Ball CA, Blake JA, Botstein D, Butler H, Cherry JM, et al. Gene ontology: tool for the unification of biology. Nat Genet. 2000;25:25-9.

\section{Submit your next manuscript to BioMed Central and we will help you at every step:}

- We accept pre-submission inquiries

- Our selector tool helps you to find the most relevant journal

- We provide round the clock customer support

- Convenient online submission

- Thorough peer review

- Inclusion in PubMed and all major indexing services

- Maximum visibility for your research

Submit your manuscript at www.biomedcentral.com/submit 